\title{
DiVA
}

http://uu.diva-portal.org

This is an author produced version of a paper published in Ratio Juris. This paper has been peer-reviewed but does not include the final publisher proof-corrections or journal pagination.

Citation for the published paper:

Spaak, Torben

"Karl Olivecrona on Judicial Law-Making"

Ratio Juris, 2009, Vol. 22, Issue 4: pp. 483-498

http://dx.doi.org/10.1111//.1467-9337.2009.00436.x

The definitive version is available at www.blackwell-synergy.com. Access to the published version may require subscription.

Published with permission from: Blackwell Publishing 


\section{Karl Olivecrona on Judicial Law-Making}

\section{Torben Spaak ${ }^{*}$}

\section{INTRODUCTION}

Karl Olivecrona maintains that courts necessarily create law when deciding a case. The reason, he explains, is that judges must evaluate issues of fact or law in order to decide a case, and that evaluations are not objective. I am not convinced by Olivecrona's analysis, however. The problem is that Olivecrona uses the term 'evaluation' in a broad enough sense to cover not only evaluations, including moral evaluations, but also considerations that are not evaluations at all, and that therefore his claim that judges must evaluate issues of law or fact in order to decide a case is false.

I begin with a consideration of the structure of Olivecrona's argumentation in support of the claim that courts necessarily create law when deciding a case (Section 2), adding a few words about the distinction between law application and judicial law-making (Section 3). I then consider Olivecrona's tacit assumption that the occurrence of non-objective judicial evaluations must lead to judicial law-making (Section 4), the central claim that courts must evaluate issues of fact or law in order to decide a case (Section 5), and Olivecrona's metaethics (Section 6). Having done that, I consider and reject an alternative interpretation of Olivecrona's confusing ideas about evaluations (Section 7). I state my conclusions in Section 8.

\section{The StRucture OF OlivecronA’s ARgumentATION}

In the second edition of Law as Fact, Olivecrona makes a distinction between executory judgments, which order the defendant to do something, declaratory judgments, which declare the existence of a certain legal relation, and constitutive judgments, which create a legal relation where there previously was none or dissolve an existing legal relation. ${ }^{1}$ He treats executory and declaratory judgments in turn. ${ }^{2}$ Having explained that an executory judgment orders the defendant to do something, and that the imperative included in the judgment is significant in two ways - by exerting pressure on the defendant and by putting the executive authorities at the disposal of the plaintiff - he argues that the imperative is the essential

\footnotetext{
* Professor in Jurisprudence, Department of Law, Uppsala University. This article reports research carried out under the auspices of The Bank of Sweden Tercentenary Foundation. I would like to thank Brian Bix and Thomas Mautner for helpful comments on this article. I would also like to thank Åke Frändberg and the participants in the advanced seminar in jurisprudence at the Department of Law, as well as the participants in the advanced seminar in practical philosophy at the Department of Philosophy, Uppsala University, for helpful comments on an earlier version of this article. In addition, I would like to thank the participants in the special workshop "Legal Argumentation and Interpretation” at the IVR conference in Cracow, Poland, 1-6 August 2007, for equally helpful comments on my presentation of the ideas put forward in the article. Finally, I would like to thank Robert Carroll for checking my English. The usual caveat applies, however: The author alone is responsible for any remaining mistakes and imperfections.

${ }^{1}$ Karl Olivecrona, Law as Fact. $2^{\text {nd }}$ ed. (London: Stevens \& Sons, 1971) pp. 200-1. Examples of executory judgments include judgments that order a person to pay somebody else a sum of money; examples of declaratory judgments include judgments declaring that a certain person is the lawful owner of a certain object; and examples of constitutive judgments include judgments that dissolve a marriage or a company.

${ }^{2}$ For some reason, he does not treat constitutive judgments.
} 
element in the executory judgment, whether it refers to the existence of a right or not. ${ }^{3}$ And he points out that although many different formulae are used in declaratory judgments, they all have a directive function in that they indicate the correct behavior of the parties on the point in dispute. ${ }^{4}$

Olivecrona proceeds to argue that in deciding a case the court is creating law for the particular case, because there will always be a margin to decide between two alternative interpretations of the pertinent legal rule. ${ }^{5}$ He puts it as follows:

\begin{abstract}
The actual role of the courts is that of being a lawgiver for particular cases. The legal rules, whether laid down through acts of legislation or evolved in some other way, cannot supply exact patterns of behaviour for every contingency. There is always a more or less wide margin for deciding which of two or more alternatives are to be deemed lawful. The margin is so small as to be (in general) negligible when you put your name on the back of a bill of exchange. If you have been involved in an accident when driving your car, the margin may be very wide. All of us have to apply the rules of civil law in our relations with our fellow-citizens. In a great many simple cases, for instance when we pay a tradesman's bill, we know what we have to do without asking anybody for advice. When difficulties arise, we have to consult a legal expert. But the experts may disagree. There must be some ultimate authority capable of giving a definite answer to the question of lawful behaviour in the situation. This task is entrusted to the courts. They supplement abstract rules of law by laying down particular rules for individual cases. ${ }^{6}$
\end{abstract}

The reason why there will always be a margin, or, if you prefer, why the judge will always have discretion, he explains, is that the judge must evaluate the purported operative facts or legal texts in order to decide the case, and that evaluations are not objective. ${ }^{7}$ He does not, however, discuss the status of evaluations in this context, but simply assumes that they are not objective; and this, of course, is in keeping with his endorsement of Axel Hägerström's metaethical theory. As we shall see below (in Section 6), Hägerström was a staunch moral antirealist who defended a noncognitivist theory and, it seems, at times, an error-theory of moral judgments.

To illustrate the way in which the judge must evaluate a purported operative fact, Olivecrona considers a hypothetical case in which $P$ requires payment from $D$ for goods delivered in accordance with a contract of sale. ${ }^{8} P$ maintains that $P$ and $D$ were involved in talks that resulted in a contract being concluded, whereas $D$, although he agrees that the talks took place roughly as described by $P$, objects that no deal was ever concluded. What should the court do? Having pointed out that the law on sale of goods presupposes that there is a contract of sale to begin with, Olivecrona explains (i) that the court cannot simply compare the facts as described by the parties with a description in the law of how a contract is concluded, because there is no such description in the law. Moreover, he continues, (ii) although the law reports may include a number of cases that concern the question whether a contract has been concluded, the case at bar will always be different in some respects from the cases in the law reports. He adds (iii) that the textbooks will not contain sufficient information on this question. Olivecrona concludes that for these reasons, the court itself will have to decide whether a contract has been concluded or not. And, he insists, such a decision necessarily presupposes an evaluation of the purported operative facts:

\footnotetext{
${ }^{3}$ Olivecrona, Law as Fact, supra note 1, at p. 209. The second way in which the imperative included in the judgment is said to be significant is rather weak.

${ }^{4} I d$. at p. 210 . The imperative aspect of the directive function identified by Olivecrona is rather weak.

${ }^{5} I d$. at p. 211.

${ }^{6}$ Id. at p. 211. (Emphasis added)

${ }^{7}$ Id. at pp. 212-5.

${ }^{8}$ Id. at pp. $212-3$.
} 
The real reason for the decision to apply the rules of sale and purchase is the evaluation resulting in finding that these rules ought to be applied. Nothing substantial is added by the declaration that a contract for sale and purchase has been concluded. But this declaration is of psychological importance. Since the law refers to the apparent fact that a contract for sale and purchase has been concluded, it seems necessary that the court, before applying the law of sale and purchase to the case, declares that such a contract has really been concluded. It is not generally realized that such a declaration is made on the basis of an evaluation; the declaration is taken to be the ascertainment that a fact has taken place. The real situation is that the law, in referring to the circumstance that a contract has been concluded, presupposes a general notion of a contract, which it is, however, impossible to define exhaustively in factual terms. Therefore, it is of necessity left to the courts to evaluate in each case an alleged transaction as being, or not being, of such a character that the rules of sale and purchase ought to be applied. ${ }^{9}$

More generally, Olivecrona maintains that there is necessarily an element of evaluation involved when a court classifies an action or an event as an operative fact, or a text as a statute or a precedent:

\begin{abstract}
There are no operative facts in nature but only in legal language. Since the law refers to 'operative' facts under such names as contract, promise, payment, marriage, etc., alleged facts have to be classified by the courts under such headings. This is a step in the application of the law. It requires something more than ascertaining some facts: these facts have also to be evaluated, with the result that the court either declares them to constitute a contract, a promise, a payment, a marriage, etc., or rejects the proposed classification.

Likewise, evaluations are made with regard to the law. A text is evaluated as belonging to the law in force; a previous decision is evaluated as being a precedent with bearing on the case now before the court; an utterance of a judge is evaluated as being an obiter dictum etc. Law and precedents are not 'pure facts'. Texts and pronouncements are evaluated when they are classified as laws and precedents. ${ }^{10}$
\end{abstract}

Olivecrona observes in conclusion that although judges often agree in their evaluations, because they have absorbed a "common stock" of evaluations, there will nevertheless be debatable cases in which they have to "strike out" on their own. He adds that the evaluations are never rigidly fixed, but are always undergoing changes. ${ }^{11}$

We see that Olivecrona's argumentation in support of the claim that courts are lawmakers in the particular case has the structure of a modus ponens inference: (P\&Q $\supset \mathrm{R}) \&(\mathrm{P} \& \mathrm{Q}) \supset$ $\mathrm{R}$ :

(P1) If courts have to evaluate operative facts or legal texts in order to decide a case (P), and if evaluations are not objective (Q), then courts necessarily create law when deciding a case (R).

(P2) Courts have to evaluate operative facts or legal texts in order to decide a case (P).

(P3) Evaluations are not objective (Q).

(C) Courts necessarily create law when deciding a case (R).

We now need to take a closer look at the premises (P1)-(P3). But before we do, we should briefly consider the distinction between law application and judicial law-making.

\footnotetext{
${ }^{9}$ Id. at p. 213. (Emphasis added)

${ }^{10} \mathrm{Id}$. at p. 214. (Emphasis added)

${ }^{11}$ Id. at p. 215.
} 


\section{LAW APPLICATION AND JUDICIAL LAW-MAKING}

The reason why the topic of judicial law-making is interesting is, of course, that judicial lawmaking is incompatible with the separation of powers doctrine, according to which each branch of the government - the executive, the legislative, and the judicial - may operate within the sphere allotted to that particular branch, and only within that sphere. ${ }^{12}$ If Olivecrona is right, courts necessarily create law, and thus never apply pre-existing law, when deciding cases. Hence they consistently violate the separation of powers doctrine. ${ }^{13}$

Although important, the underlying distinction between law application and judicial lawmaking is rather difficult to pin down. The question is: In what circumstances are we justified in saying that courts create new law rather than apply pre-existing law? But in order not to be distracted by the doctrine of stare decisis, which is accepted in some jurisdictions but not in others, we should ask instead: In what circumstances are we justified in saying that courts create new law in the particular case rather than apply pre-existing law?

Generally speaking, I believe there are clear cases of law application and clear cases of judicial law-making, and quite a few cases that are unclear in this regard. For example, most legal scholars would hold that a decision made in accordance with a textual interpretation of the relevant statutory provision is a clear case of law application, and that a decision outside or contrary to the wording of a provision unsupported by any recognized interpretive argument(s) is a clear case of judicial law-making. But what about a decision outside or contrary to the wording of the provision based on, say, good intentionalist or teleological arguments? Would this be a case of judicial law-making? I think not - to answer this question in the affirmative would amount to saying that there is a good deal of judicial law-making going on in courts around the world, and I am not prepared to say that. ${ }^{14}$

One might argue that the reason why the topic of judicial law-making is interesting is not primarily that judicial law-making is incompatible with the separation of powers doctrine, but that judges, unlike legislators, are not (normally) elected. On this analysis, judicial lawmaking is not primarily a separation of powers problem, but a democracy problem. ${ }^{15} \mathrm{I}$ believe, however, that the "democracy argument" is best understood not as an independent argument in support of a prohibition of judicial law-making, but rather as an argument in support of the separation of powers doctrine: we accept the separation of powers doctrine, at least partly because we believe that whereas unelected officials may apply pre-existing law created by democratically elected representatives, they should not create new law.

\section{EVALUATIONS AND JUDICIAL LAW-MAKING}

As we have seen, Olivecrona maintains (P1) that if courts have to evaluate operative facts or legal texts in order to decide a case, and if evaluations are not objective, then courts necessarily create law when deciding cases. He does not, however, explain why the occurrence of non-objective judicial evaluations would have to lead to judicial law-making.

\footnotetext{
${ }^{12}$ I discuss judicial law-making in light of the separation of powers doctrine elsewhere. See Torben Spaak, Guidance and Constraint: The Action-Guiding Capacity of Theories of Legal Reasoning (Uppsala: Iustus förlag, 2007) pp. 270-4.

13 Olivecrona's stance in this regard is both similar to and different from that of Hans Kelsen. Kelsen, as is well known, holds that every act of judicial decision-making is both an act of law application and an act of judicial law-making. Hans Kelsen, Reine Rechtslehre (Wien: Österreichische Staatsdruckerei, 1960) p. 347.

${ }^{14}$ But see, e.g., Trevor C. Hartley, "The European Court, Judicial Objectivity and the Constitution of the European Union,” Law Quarterly Review 112 (1996) pp. 95-109.

${ }^{15}$ Ronald Dworkin appears to prefer this analysis. See Ronald Dworkin, Taking Rights Seriously. $2^{\text {nd }}$ ed. (London: Duckworth, 1978) pp. 84-5.
} 
Nevertheless, I accept his claim. For it seems to me that if courts had to evaluate issues of fact or law in order to decide a case, and if evaluations were not objective, so that there would be no uniquely correct way to evaluate, then the existence or content of law, or both, would depend on evaluations none of which would be more correct than the other; and this means that there would be no law for the court to apply prior to the evaluation. And if courts could not apply pre-existing law, they would have to create new law.

Exclusive legal positivists might object to this line of reasoning that there would be no preexisting law to apply for the court even if evaluations were objective. For on the exclusive positivist analysis, we determine the existence and content of the law using exclusively factual criteria. ${ }^{16}$ On this analysis, if the rule of recognition (if there is one) or an ordinary legal norm refers the judge to moral considerations, then a judge who decides the case on the basis of such moral considerations exercises his discretion and does not apply pre-existing law. ${ }^{17}$ On the inclusive positivist analysis, on the other hand, a judge who decides the case on the basis of such moral considerations determines the existence and content of the law. ${ }^{18}$ My own view is that whereas exclusive legal positivism is correct at the level of the sources of law (the existence of law), inclusive legal positivism is correct at the level of interpretation and application of the law (the content of law). ${ }^{19}$

We might see the place of evaluations in judicial decision-making a bit clearer if we adopt a mode of analysis suggested by Åke Frändberg. ${ }^{20}$ Frändberg, who conceives of judicial decision-making as involving the application of a legal norm to the facts at hand, distinguishes the following components of the legal syllogism:

Premise 1: the base norm (the general legal norm as it appears in the relevant piece of legislation or case law)

Premise 2: the subsumption norm (the more specific norm that is a result of an interpretation of the base norm and more precisely fits the facts of the case at bar)

Premise 3: the evidence claim (which states the facts)

Conclusion: the individual norm (which is formulated in terms of the parties and the facts of the case at bar, such as “Smith shall pay Jones \$500 no later than 1 September 2008”)

Frändberg points out that, on this analysis, to decide a case by applying the law to the facts necessarily involves an act of qualification, which takes the judge from the base norm to the subsumption norm. Now if Olivecrona is right, this is also where judicial evaluations enter the picture. We might say that, on Olivecrona's analysis, the act of qualification is necessarily an act of evaluation. To be sure, whereas Frändberg's act of qualification seems to concern the base norm, not the facts of the case, Olivecrona's act of evaluation clearly concerns the facts of the case, not the base norm. The difference may not be as big as it seems, however, because the judge will interpret the base norm in light of the facts of the case, and he will view the facts in light of the base norm. If this is so, then Frändberg's act of qualification will to some

${ }^{16}$ See Joseph Raz, "Legal Positivism and the Sources of Law," in Joseph Raz, The Authority of Law (Oxford: Clarendon Press, 1979) pp. 37-52.

${ }^{17}$ See Joseph Raz, “Dworkin: Another Link in the Chain,” California Law Review 74:3 (1986) pp. 1103-19, at 1115.

${ }^{18}$ See, e.g., W. J. Waluchow, Inclusive Legal Positivism (Oxford: Oxford University Press, 1994).

${ }^{19}$ For more on this topic, see Torben Spaak, "Legal Positivism, Law's Normativity, and the Normative Force of Legal Justification” 16:4 Ratio Juris (2003) pp. 469-85, at 472-3. I would like to thank Åke Frändberg for drawing my attention to this difficulty in my analysis.

20 Åke Frändberg, Om analog användning av rättsnormer (Stockholm: P. A. Norstedt och söners förlag, 1973) pp. 83-8. 
extent concern the facts of the case, and Olivecrona's act of evaluation will to some extent concern the base norm.

One might, however, object to my reconstruction of Olivecrona's line of reasoning that subjectivity (non-objectivity) does not imply arbitrariness. That is to say, one might object that even if evaluations are not objective in the strong, realist sense presupposed above, which assumes the existence of mind-independent evaluative facts, we have reason to reckon with a weaker, constructivist type of evaluative objectivity, which only assumes the existence of evaluative facts that are, in some sense, constructed by the people concerned, such as the legal community. ${ }^{21}$ If this constructivist type of evaluative objectivity could be defended, we might say that courts evaluating issues of fact or law are indeed applying pre-existing law and thus not creating new law.

The main problem with this line of reasoning is that the condition that must be satisfied for it to apply - that the relevant group of people are in such agreement about values that we would be entitled to say that these values somehow exist by virtue of this consensus - will rarely be satisfied in the real world. Nevertheless, one may well wonder why Olivecrona did not consider the possibility of such a constructivist evaluative objectivity, given his belief in a "common stock" of evaluations on the part of judges. ${ }^{22}$

\section{EVALUATIONS IN JUDICIAL DECISION-MAKING}

Olivecrona maintains, as we have seen, (P2) that courts have to evaluate purported operative facts or legal texts in order to decide a case. I cannot, however, accept this claim. As I see it, Olivecrona misconceives the nature of evaluations, and, as a result, exaggerates their incidence. Whereas he appears to believe that judicial evaluations are necessarily moral evaluations, I argue that they are not evaluations at all, at least not moral evaluations. I shall explain what I mean with the help of a few examples.

Let us begin with Olivecrona's thoughts on operative facts. Consider Olivecrona's claim that there is no definition of the concept of a contract for sale in the (Swedish) Sale of Goods Act, and that there will be nothing in the law reports or in the legal literature that could help the judge determine whether a purported contract is a legally valid contract. These are empirical claims, which may or may not be true in the particular case. Since this is so, they could not support a claim of necessity - that courts have to evaluate purported operative facts in order to decide a case - even if they were true. ${ }^{23}$

Consider also Olivecrona's analysis of the concept of a sale, as the author presents it in a private letter to professor Torstein Eckhoff at the University of Oslo. Here Olivecrona maintains that it is impossible to describe operative facts without making use of evaluative language:

For one cannot describe, e.g., a sale as consisting in two persons uttering certain words to each other. The words could of course be spoken at the theater or for the sake of practice. There is always an added element of evaluation. One judges that the transaction should be designated

\footnotetext{
${ }^{21}$ I have in mind here a conventionalist analysis of the type suggested by Eerik Lagerspetz in his book on different types of institution, such as 'marriage' and 'the state.' Eerik Lagerspetz, The Opposite Mirrors (Dordrecht: Kluwer, 1995) Ch. 1.

${ }^{22}$ See Section 2 above and the quotation from Olivecrona's letter to Torstein Eckhoff in Section 5 below.

${ }^{23}$ Moreover, they seem to be either false or irrelevant. For example, while there is no definition of the concept of a contract for sale in the (Swedish) Sale of Goods Act, articles 1-9 in the (Swedish) Contracts Act make it clear that a contract is made up of an offer and an acceptance, and that offers as well as acceptances are binding. And this (implicit) definition of the concept of a contract is clearly applicable to Olivecrona's case. The Contracts Act was part of Swedish law at the time Olivecrona wrote the book.
} 
"sale", which involves one's thinking it fulfills the demands that the law can be considered to make for a transaction to be worthy of having legal sanctions attached. A subjective element is thus added. We all make such evaluations constantly without any difficulty at all. Only in those few cases when a question of the transaction's "validity" is brought up in a trial, does there arise any difficulty for the judges to make the evaluation. It is necessarily subjective, even though the judges have certain relatively uniform grounds for their evaluations. ${ }^{24}$

I am not persuaded by Olivecrona's analysis, however. He asserts without explanation that a judge who finds that a purported transaction should be labeled a sale necessarily evaluates the transaction, in the sense that he believes that it satisfies the conditions laid down in the law for something to be worthy of being labeled a sale. I cannot, however, see that in doing so the judge necessarily evaluates the transaction, except in a trivial and derivative sense. For such an evaluation depends completely on his prior determination of the facts.

Consider in this regard the case of a school teacher who is correcting a multiple-choice exam, and in doing this finds that one of his students has managed to answer correctly each and every question on the exam. On the basis of this result, the teacher awards the student the highest grade there is. Does the teacher's awarding the student the highest grade mean that the teacher must have evaluated the student's answers? No, of course not! If, as in this case, the teacher can determine, on the basis of factual considerations, whether the student has answered the questions correctly, then the circumstance that (pursuant to the relevant university rules and regulations) the teacher also must award the student a certain grade is completely irrelevant to the question whether his awarding the student a certain grade necessarily involves an evaluation of the answers. Although one may well say that the teacher evaluates the exam that he grades, such an evaluation is trivial and derivative in that it depends completely on his prior determination of the facts, that is, the answers to the questions posed. And it seems to me that the judge's determination of the purported operative facts in a legal rule proceeds in the same way, even though this determination may sometimes be very difficult to make.

If, then, Olivecrona really believes that the judge must evaluate the purported operative facts or, perhaps, the whole situation, in order to determine, say, whether $A$ and $B$ have entered into a legally valid contract, he must be using the term 'evaluation' in a broad enough sense to cover not only evaluations, including moral evaluations, but also considerations that are not evaluations at all. That is to say, Olivecrona's claim that judges have to evaluate the purported operative facts in order to decide a case depends on a confused view about the nature of evaluations, including moral evaluations.

One might, however, object to my line of reasoning that, although he did not say so, Olivecrona might have reasoned that since the legal consequence in a legal norm is normative (or evaluative), and since Hume's Law has it that a normative (or evaluative) conclusion cannot be derived from a set of purely factual premises, ${ }^{25}$ the operative fact(s) must also be normative (or evaluative). ${ }^{26}$ I cannot accept this line of reasoning, however, because the relation between operative facts and legal consequences in a legal norm is not one of (material or strict) implication, but rather one of imputation (Zurechnung), as Hans Kelsen has

\footnotetext{
${ }^{24}$ Karl Olivecrona’s letter of 18 June 1969 to professor Torstein Eckhoff. (Emphasis added) Translated into English by Robert Carroll. I would like to thank Thomas Mautner for kindly providing me with a transcription of this letter. The transcription is on file with the author of this article.

${ }^{25}$ David Hume, A Treatise on Human Nature. Ed. Ernest C. Mossner (London: Penguin Books, 1969 [1739 and 1740]) p. 521.

${ }^{26}$ I would like to thank Jan Österberg for suggesting this way of understanding Olivecrona's line of argumentation.
} 
suggested. ${ }^{27}$ On Kelsen's analysis, it is the concept of ought that connects the operative facts and the legal consequence in a legal norm, and in doing so it distinguishes the relation of imputation from the relation of cause and effect. Although Kelsen did not specifically consider the difference between imputation and (material or strict) implication, he clearly considered imputation to be something entirely different from (material or strict) implication. And I share his view.

Consider also Olivecrona's claim that judges must evaluate a purported legal text, such as a statute or a precedent, in order to determine whether it is really a legal text. I cannot accept this claim either. Whereas one might argue that in some cases the court cannot avoid evaluative, specifically moral, considerations in the interpretation of a statute or a precedent, it is just plain false to maintain that it has to evaluate a purported statute or precedent in order to determine whether it is legally valid. ${ }^{28}$ That is to say, I take it for granted that legal positivists are right to insist that the determination of the law is a purely factual matter, if and to the extent we are concerned with matters of existence or validity, as distinguished from matters of interpretation and application. H. L. A. Hart's characterization of the rule of recognition, whose function is to indicate the sources of law in the relevant legal system (such as legislation, precedent, custom), illustrates this notion:

\begin{abstract}
The question whether a rule of recognition exists and what its content is, i.e., what the criteria of validity in any given legal system are, is regarded throughout this book as an empirical, though complex, question of fact. This is true even though it is also true that normally, when a lawyer operating within the system asserts that some particular rule is valid he does not explicitly state but tacitly presupposes the fact that the rule of recognition . . . exists as the accepted rule of recognition of the system. If challenged, what is thus presupposed but left unstated could be established by an appeal to the facts, i.e., to the actual practice of the courts and officials of the system when identifying the law which they are to apply. ${ }^{29}$
\end{abstract}

To be sure, the legal positivist view that judges determine the existence or validity of law using (exclusively or essentially) factual criteria is not universally accepted. Ronald Dworkin, for example, argues that the judge cannot determine what the law is, except by engaging in moral and political reasoning. ${ }^{30}$ But first of all, Dworkin's theory aims at moral justification of "the settled law," 31 and this must reasonably mean that he believes that "the settled law" is a fairly uncontroversial matter, that is, a matter of empirical fact. Second, whereas Dworkin adduces a complex and intriguing theory in support of his claim, Olivecrona does not offer much in the way of argumentation in support of his claim; and he certainly would not accept Dworkin's theory or anything resembling it.

\title{
6. OliveCRONA ON THE NATURE OF EVALUATIONS
}

I have argued that Olivecrona's claim about operative facts depends on a confused view about the nature of evaluations, and that the claim about statutes and precedents is just plain false. Let us, however, assume, for the sake of argument, that Olivecrona's claim about operative facts is true. The question, then, is whether Olivecrona is right to maintain (P3) that

\footnotetext{
${ }^{27}$ Hans Kelsen, Introduction to the Problems of Legal Theory. Trans. Bonnie Litschewski Paulson and Stanley L. Paulson (Oxford: Clarendon Press, 1992) pp. 23-5.

${ }^{28}$ For more on this topic, see Torben Spaak, "Legal Positivism and the Objectivity of Law," in Paolo Commanducci \& Riccardo Guastini (eds) Analisi e diritto (2004) pp. 253-67.

${ }^{29}$ H. L. A. Hart, The Concept of Law (Oxford: Clarendon Press, 1961) p. 245.

${ }^{30}$ See Dworkin, TRS, supra note 15, Ch. 4; Ronald Dworkin, Law's Empire (Cambridge, Massachusetts \& London, England: The Belknap Press, 1986) Ch. 7.

${ }^{31}$ See, e.g., Dworkin, LE, supra note 30, at pp. 65-8. Here Dworkin speaks of the "preinterpretive stage.”
} 
evaluations are not objective. This question is worth considering separately, even though we already have found reason to reject (P2), and with it the conclusion of Olivecrona's line of argumentation: that courts necessarily create law when deciding a case. For having done that, we will have gained a better understanding of the strengths and weaknesses of Olivecrona's argumentation taken as a whole.

Although Olivecrona never speaks of moral values or moral rights or obligations, as distinguished from other types of value, right, or obligation, but prefers to speak more generally of values, rights, or obligations, etc., it is clear from the context that he usually has in mind precisely moral values, rights or obligations. ${ }^{32}$ And he endorses the meta-ethics espoused by Axel Hägerström, who was a staunch moral anti-realist in the sense that he believed that there are no such things as mind-independent moral facts. ${ }^{33}$

Olivecrona's precise view of moral evaluations or moral judgments is not easy to determine, however. First, although Hägerström is commonly considered to have been a noncognitivist, ${ }^{34}$ it has been argued by some philosophers that at times he defended instead a so-called error-theory of moral judgments. ${ }^{35}$ Whether or not Hägerström himself was fully aware of his vacillation between noncognitivism and error-theory, if indeed there was one, there is no evidence that Olivecrona paid any attention to it, or that he even noticed it. Second, Olivecrona's claim that there are no objective (in the sense of mind-independent) moral facts could be accepted not only by noncognitivists, but also by moral constructivists and errortheorists. ${ }^{36}$ Luckily, I do not need to determine Olivecrona's precise meta-ethical view in order to assess his claim about judicial law-making. I shall, however, assume, for the purposes of this analysis, that his moral anti-realism is well founded.

Since Olivecrona does not make a sharp distinction between moral and non-moral values, rights, or obligations, it is reasonable to assume that he believes that his analysis applies to both types. I take a different view, however. Whereas I agree with Olivecrona that moral

${ }^{32}$ See, e.g., Karl Olivecrona, "Realism and Idealism: Some Reflections on the Cardinal Point in Legal Philosophy,” New York University Law Review 26 (1951) pp. 120-31; Olivecrona, Law as Fact, supra note 1, chs 1 and 3 .

${ }^{33}$ For more about moral anti-realism, see David O. Brink, Moral Realism and the Foundation of Ethics (Cambridge. Cambridge University Press, 1989) Ch. 2.

${ }^{34}$ Noncognitivists maintain that a person who makes (what appears to be) a moral judgment is simply expressing his attitudes or preferences, or, perhaps, prescribing a course of action. See Axel Hägerström, "On the Truth of Moral Propositions,” in Axel Hägerström, Philosophy and Religion (New York: Humanities Press, 1964) pp. 33-74. See also A. J. Ayer, Language, Truth, and Logic. 2nd ed. (London: Victor Gollancz, 1947) Ch. 6; Simon Blackburn, Ruling Passions (Oxford: Oxford University Press, 1998); Alan Gibbard, Wise Choices, Apt Feelings (Cambridge, Massachusetts: Harvard University Press, 1990); R. M. Hare, Moral Thinking (Oxford: Oxford University Press, 1981); Ingemar Hedenius, Om rätt och moral. 2nd ed. (Stockholm: Wahlström \& Widstrand, 1963) pp. 12-34; Charles L. Stevenson, Ethics and Language (New Haven: Yale University Press, 1944). On this type of analysis, moral judgments function rather as a means to influence people. See, e.g., Hedenius, rätt och moral, at pp. 53-4. Noncognitivists tend to believe, in keeping with this, that there are no moral facts and that there is no such thing as moral knowledge. For a brief discussion of this question, see Lars Bergström, Grundbok i värdeteori (Stockholm: Thales, 1990) pp. 66-7.

${ }^{35}$ See, e.g., Andries H. D. Mac Leod, “Om ett värdeobjektivistiskt inslag i Hägerströms moralfilosofiska teorier,” in Andries H. D. Mac Leod, Tre uppsatser om Hägerström, Zenon från Elea och relativitetsteorin (Uppsala: Filosofiska föreningen och filosofiska institutionen vid Uppsala universitet, 1973) pp. 1-28, at 19-20. Like noncognitivists, error-theorists believe that there are no moral facts and no moral knowledge, but, unlike noncognitivists, they believe that moral judgments do assert something about something. Hence they believe that moral judgments are always false. For more on this type of meta-ethical theory, see Richard Joyce, The Myth of Morality (Cambridge: Cambridge University Press, 2003). See also J. L. Mackie, Ethics (London: Penguin Books, 1977) Ch. 1.

${ }^{36}$ Like moral realists, moral constructivists hold that there are moral facts, though they insist that those facts are constituted by our moral beliefs and feelings, etc. On this analysis, moral facts are mind-dependent, not mind-independent. For more on this topic, see Brink, Moral Realism, supra note 33, at pp. 17-22. 
evaluations are non-objective in the sense indicated, I am inclined to believe that other types of evaluation (except aesthetic evaluations) are, or at least can be, objective. As I see it, moral evaluations are non-instrumental, whereas other types of evaluation are instrumental, in the sense that they can be reduced to judgments about the existence (or non-existence) of factual criteria. ${ }^{37}$ For example, many maintain that a scientific theory is adequate if (and only if) it is (i) empirically accurate, (ii) internally consistent and consistent with other established theories in the field, (iii) has broad scope of application, and is (iv) simple and (v) fruitful; ${ }^{38}$ and these conditions appear to be essentially factual and therefore objective, although their precise interpretation and relative weight may perhaps be said to be non-objective. Similarly, the evaluations, discussed above (in Section 5), of purported operative facts or answers to a multiple-choice exam are usually judgments about the existence or non-existence of factual criteria; and as such they are objective. We should note, however, that the subjective element that comes into play when we are concerned with the precise interpretation or relative weight of the scientifically relevant values (i)-(v), although perhaps present in the case of the multiple-choice exam, appear to be absent in the case of the judge's determination of the operative facts.

\section{CONVENTION, NOT EVALUATION}

If I am right, Olivecrona uses the term 'evaluation' in a broad enough sense to cover not only evaluations, including moral evaluations, but also considerations that are not evaluations at all. But, one may wonder, why did he do that? Why did he speak of evaluations in such a loose and imprecise manner? One possibility is that he had in mind not evaluations in the sense explained above, but conventions, as distinguished from brute facts of nature. ${ }^{39}$ More specifically, he might have meant that the existence of legal norms and legal relations is a matter of convention, not a matter of brute fact, and that therefore a judgment that a certain operative fact is at hand or that a certain text is a legal text is a conventional, as distinguished from an empirical, judgment.

On this interpretation, premise (1) in Olivecrona's argumentation - If courts have to evaluate operative facts or legal texts in order to decide a case, and if evaluations are not objective, then courts necessarily create law when deciding cases - is transformed into premise $\left(1^{*}\right)$ : If courts have to make conventional judgments about operative facts or legal texts in order to decide a case, and if conventional judgments are not objective, then courts necessarily create law when deciding cases; premise (2) in Olivecrona's argumentation Courts have to evaluate operative facts or legal texts in order to decide a case - is transformed into premise $(2 *)$ : Courts have to make conventional judgments about operative facts or legal texts in order to decide a case; and premise (3) - Evaluations are subjective - is transformed into premise (3*): Conventional judgments are subjective.

This interpretation gains support from Olivecrona's introduction, in a chapter entitled "Legal Language and Reality," of a distinction between truth and correctness. ${ }^{40}$ Having argued that legal statements - statements about the existence and content of legal rights or

\footnotetext{
${ }^{37}$ For more on this topic, see Georg Henrik von Wright, The Varieties of Goodness (London: Routledge \& Kegan Paul, 1963) Ch. 2, especially pp. 24-9. See also H. L. A. Hart, "Lon L. Fuller: The Morality of Law," in H. L. A. Hart, Essays in Jurisprudence and Philosophy (Oxford: Clarendon Press, 1983) pp. 343-64, at 350.

${ }^{38}$ For a presentation of these requirements, see Thomas S. Kuhn, “Objectivity, Value Judgment, and Theory Choice,” in Thomas S. Kuhn, The Essential Tension (Chicago \& London: The University of Chicago Press, 1977) pp. 320-39.

39 I would like to thank Thomas Mautner for suggesting this possibility.

${ }^{40}$ Law as Fact, supra note 1, at pp. 259-67.
} 
duties - fulfill an informative as well as a directive function in legal discourse, Olivecrona explains that in regard to its informative aspect, a legal statement may be correct or incorrect, but not true or false. On Olivecrona's analysis, the correctness of a legal statement consists in the conformity of the statement to an effective system of rules, whereas the truth of such a statement would consist in the conformity of the statement to brute facts. And since A's ownership of a house, $X$, or $B$ 's being a judge, is not an empirical fact, presupposing as it does the existence of legal rules, the statement that $A$ owns $X$ or that $B$ is a judge cannot, on Olivecrona's analysis, be true or false, but only correct or incorrect.

Olivecrona sees a close relation between correctness thus conceived and evaluations. He writes: “ . . . the ascertainment of correctness presupposes the evaluation of a certain system of rules as valid and the adherence to some more or less common scales of value." ${ }^{41}$ On the suggested interpretation, he is really saying not that the ascertainment of correctness presupposes an evaluation of a certain system of rules as valid, but that it presupposes a conventional judgment that the system is valid. And this makes good sense to me.

But the suggested interpretation is nevertheless quite problematic. The problem is that both premise $\left(2^{*}\right)$ and premise $\left(3^{*}\right)$ turn out to be false; and this means that Olivecrona will not be able to establish the conclusion he wants. The reason why premise $\left(2^{*}\right)$ is false is that the judgment that a certain operative fact is at hand - as distinguished from the judgment that a certain text is a legal text - will not always be a conventional judgment. For not all operative facts are conventional facts. Thus while it is clear that a person's being a Swedish citizen or a high court judge is a conventional fact, it is equally clear that one person's killing another or a seller's delivering a product too late is not. ${ }^{42}$ The reason why premise $\left(3^{*}\right)$ is false is that unlike moral judgments, conventional judgments are, or at least can be, objective in the sense of constructivist objectivity considered in Section 4 above. The difference between the moral and the conventional case is that the necessary and sufficient condition for constructivist objectivity - that the members of the relevant group of people are in agreement about whatever it is that they need to agree about - will be satisfied in many cases of conventional judgments, but not in many cases of moral judgments. Hence from the point of view of the soundness of Olivecrona's inference, we are back where we began.

\section{CONCLUSION}

We have seen that Olivecrona argues (P1) that if courts have to evaluate operative facts or legal texts in order to decide a case, and if evaluations are not objective, then courts necessarily create law when deciding cases, (P2) that courts have to evaluate operative facts or legal texts in order to decide a case, (P3) that evaluations are not objective, and (C) that therefore courts necessarily create law when deciding cases. I have argued that Olivecrona's argumentation does not stand up to scrutiny, because even though (P1) and (P3) may be true, (P2) is false, or, alternatively, that even though ( $\left.1^{*}\right)$ and $\left(\mathrm{P} 2^{*}\right)$ may be true, $\left(\mathrm{P} 3^{*}\right)$ is false. This means that although the inference - stated in Section 3 above $-(P \& Q \supset R) \&(P \& Q) \supset$ $\mathrm{R}$ - is valid, it is not sound.

\footnotetext{
${ }^{41}$ Id. at p. 261.

${ }^{42}$ As Hans Kelsen explains, human behavior of any sort as well as natural events, such as earthquakes and floodings, can be an operative fact. Hans Kelsen, General Theory of Law and State. Trans. Anders Wedberg (Union, New Jersey: The Lawbook Exchange, 1999 [1945]) pp. 3-4.
} 